\title{
Effect of Posture on Cardiac Output after Myocardial Infarction
}

\author{
BERNARD M. GRODEN \\ From the Department of Medicine, Southern General Hospital, Glasgow S.W.1
}

The changing concepts of medical care of patients who have sustained a myocardial infarction encourage earlier mobilization and the adoption of the sitting posture in bed. It is relevant to estimate the cardiac outputs of these patients in the supine and in the seated position in bed. This paper describes an investigation in which the cardiac outputs of a series of normal controls, and of a series of patients who had recently sustained a myocardial infarction, are compared in the supine and in the seated position with the head raised.

\section{SubJECtS AND METHOdS}

Three groups of subjects have been examined.

Group 1 comprised 10 patients ( 8 men, 2 women) who were in hospital for non-cardiac reasons with the exception of one who had been admitted for the investigation by cardiac catheterization of a slight auscultatory abnormality which was considered finally to be of no significance. No patient showed either radiological or electrocardiographic evidence of cardiac or chest disease. Their ages ranged from 20-68 years (mean 35.4, SD $\pm 16 \cdot 2$ ). The procedure was fully explained to all the subjects, none of whom was connected in any way with the hospital or medical school and on none of whom was any coercion brought to bear.

Group 2 comprised 11 patients who had sustained a myocardial infarction within the 3 weeks before the investigation, but in whom there was neither clinical nor radiographic evidence of pulmonary oedema. They were all men and their ages ranged from 38 to 65 years (mean 55.4, $\mathrm{SD} \pm 9 \cdot 6$ ).

Group 3 comprised 10 male patients who had sustained a myocardial infarction and in whom there was clinical and/or radiological evidence of pulmonary oedema. Their ages ranged from 47-67 years (mean $55 \cdot 5, \mathrm{SD} \pm 8 \cdot 1)$.

The diagnosis of myocardial infarction was on the

Received February 13, 1969. basis of clinical history, electrocardiogram, and biochemical change.

All patients and subjects were examined supine (with one pillow as a head rest) and propped up at an angle of $45^{\circ}$ in their own beds with legs horizontal (Fig.). Alternate subjects were examined in the supine position first or in the $45^{\circ}$ head elevated position first. All observations were carried out more than two hours after a meal and with the patient rested but not sedated. Five minutes were allowed to elapse after a change of position before repeating the cardiac output estimation.

Cardiac output was measured by a dye-dilution technique using a photo-electric earpiece (Cambridge Instrument Co.) and Coomassie blue dye in a manner modelled on that described by Gabe and Shillingford (1961), Bruce and Shillingford (1962), Gabe, Tuckman, and Shillingford (1962), and Thomas, Malmcrona, and Shillingford (1965).

In the one patient in Group 1 who was undergoing cardiac catheterization, the dye injection was made into the superior vena cava through a No. 8 Cournand catheter, but in all other subjects a polyethylene catheter (Intracath $14 \mathrm{G}, 61 \mathrm{~cm}$. long) was inserted percutaneously into a median antecubital vein and advanced to place the tip as near the great veins as possible. Between dye injections the patency of the catheter was maintained by a slow infusion of dextrose in water with a small quantity of heparin added; $40 \mathrm{mg}$. dye $(2 \mathrm{ml}$.) were injected as a bolus through the catheter from a plastic insulin syringe, and this was followed immediately by a flushing dose of $10 \mathrm{ml}$. dextrose in water to clear the catheter. Duplicate measurements were made in each position. Dye curves were drawn from a steady baseline on a Cambridge Mark III Dye Recorder using the Cambridge photoelectric ear-piece. The first dye curve was calibrated by the tail height method. The tail height was measured 3 minutes after the injection, and at this time a blood sample was removed for estimation of plasma dye concentration and estimation of packed cell volume, which was performed using a Hawksley microhaematocrit in duplicate (Dacie and Lewis, 1963). Coomassie Blue was measured by the method suggested by the manufacturers of the dye. Proteins are precipitated and the density of the filtrate compared against a known control at $585 \mu$ in a spectrophotometer (Unicam S.P. 600). 



FIG.-Cardiac output studies: (above) patient supine; (below) patient in $45^{\circ}$ head-raised position with legs horizontal.

The area of the curve was measured by planimetry after semilogarithmic plotting and extrapolation of the down slope to the baseline and replotting on a linear scale. Subsequent cardiac outputs were calculated from the areas of the extrapolated dye curves.

Heart rate was derived from the dye curve by using the slightly incomplete pulse rejection on the dye recorder.

Means, standard deviations, and probabilities (Student's ' $t$ ' test) have been calculated in the manner suggested by Hill (1966). 
TABLE I

RESULTS OF OBSERVATIONS IN 10 SUBJECTS WITHOUT EVIDENCE OF CARDIOVASCULAR DISEASE

\begin{tabular}{|c|c|c|c|c|c|c|c|c|}
\hline \multirow[b]{2}{*}{ Subject } & \multirow[b]{2}{*}{$\begin{array}{l}\text { Age } \\
\text { (yr.) }\end{array}$} & \multirow[b]{2}{*}{ Sex } & \multicolumn{3}{|c|}{ Supine observations } & \multicolumn{3}{|c|}{ Observations at $45^{\circ}$} \\
\hline & & & $\underset{\text { (1./min.) }}{\text { Cardiac output }}$ & Pulse/min. & $\begin{array}{c}\text { Stroke volume } \\
\text { (ml.) }\end{array}$ & $\underset{(1 . / \mathrm{min} .)}{\text { Cardiac output }}$ & Pulse/min. & $\begin{array}{l}\text { Stroke volume } \\
\text { (ml.) }\end{array}$ \\
\hline $\begin{array}{l}\text { J.R. } \\
\text { A.S. } \\
\text { E.B. } \\
\text { J.J. } \\
\text { E.K. } \\
\text { J.B. } \\
\text { I.C. } \\
\text { J.P. } \\
\text { J.D. } \\
\text { A.W. }\end{array}$ & $\begin{array}{l}21 \\
68 \\
22 \\
47 \\
26 \\
36 \\
25 \\
20 \\
39 \\
50\end{array}$ & $\begin{array}{l}\mathbf{M} \\
\mathbf{F} \\
\mathbf{F} \\
\mathbf{M} \\
\mathbf{M} \\
\mathbf{M} \\
\mathbf{M} \\
\mathbf{M} \\
\mathbf{M} \\
\mathbf{M}\end{array}$ & $\begin{array}{r}6 \cdot 5 \\
6 \cdot 8 \\
4.5 \\
4 \cdot 2 \\
4.9 \\
10 \cdot 2 \\
5.0 \\
10 \cdot 2 \\
10.3 \\
5 \cdot 7\end{array}$ & $\begin{array}{l}60 \\
62 \\
88 \\
68 \\
66 \\
86 \\
64 \\
96 \\
64 \\
60\end{array}$ & $\begin{array}{r}108 \\
110 \\
51 \\
62 \\
74 \\
119 \\
78 \\
106 \\
160 \\
95\end{array}$ & $\begin{array}{r}6 \cdot 3 \\
6 \cdot 8 \\
4.5 \\
5 \cdot 1 \\
5 \cdot 5 \\
10 \cdot 5 \\
5 \cdot 2 \\
11.2 \\
9.8 \\
6 \cdot 8\end{array}$ & $\begin{array}{l}60 \\
62 \\
88 \\
66 \\
66 \\
84 \\
66 \\
96 \\
66 \\
62\end{array}$ & $\begin{array}{r}105 \\
110 \\
51 \\
77 \\
83 \\
125 \\
79 \\
117 \\
148 \\
110\end{array}$ \\
\hline $\begin{array}{l}\text { Mean } \\
\text { SD } \pm\end{array}$ & $\begin{array}{l}35 \cdot 4 \\
16 \cdot 2\end{array}$ & & $\begin{array}{l}6 \cdot 8 \\
2 \cdot 4\end{array}$ & $\begin{array}{l}71 \cdot 4 \\
13 \cdot 3\end{array}$ & $\begin{array}{l}96 \cdot 3 \\
31 \cdot 7\end{array}$ & $\begin{array}{l}7 \cdot 2 \\
2 \cdot 4\end{array}$ & $\begin{array}{l}71 \cdot 6 \\
12 \cdot 7\end{array}$ & $\begin{array}{r}100 \cdot 7 \\
27 \cdot 3\end{array}$ \\
\hline
\end{tabular}

TABLE II

RESULTS OF OBSERVATIONS IN 11 SUBJECTS, WITHOUT PULMONARY OEDEMA, WHO HAD SUSTAINED A MYOCARDIAL INFARCTION WITHIN PREVIOUS 3 WEEKS

\begin{tabular}{|c|c|c|c|c|c|c|c|c|}
\hline \multirow[b]{2}{*}{ Subject } & \multirow[b]{2}{*}{$\begin{array}{l}\text { Age } \\
\text { (yr.) }\end{array}$} & \multirow[b]{2}{*}{ Sex } & \multicolumn{3}{|c|}{ Supine observations } & \multicolumn{3}{|c|}{ Observations at $45^{\circ}$} \\
\hline & & & $\begin{array}{c}\text { Cardiac output } \\
(1 . / \mathrm{min} .)\end{array}$ & Pulse/min. & $\begin{array}{l}\text { Stroke volume } \\
\text { (ml.) }\end{array}$ & $\underset{(1 . / \mathrm{min} .)}{\text { Cardiac output }}$ & Pulse/min. & $\begin{array}{l}\text { Stroke volume } \\
\text { (ml.) }\end{array}$ \\
\hline $\begin{array}{l}\text { C.K. } \\
\text { G.A. } \\
\text { G.B. } \\
\text { A.C. } \\
\text { A.V. } \\
\text { A.F. } \\
\text { A.T. } \\
\text { J.G. } \\
\text { A.McG. } \\
\text { W.S. } \\
\text { G.R. }\end{array}$ & $\begin{array}{l}38 \\
63 \\
56 \\
63 \\
63 \\
65 \\
56 \\
42 \\
58 \\
62 \\
44\end{array}$ & $\begin{array}{l}M \\
M \\
M \\
M \\
M \\
M \\
M \\
M \\
M \\
M \\
M\end{array}$ & $\begin{array}{l}5 \cdot 8 \\
4.6 \\
3.7 \\
8 \cdot 4 \\
7 \cdot 9 \\
7 \cdot 0 \\
5 \cdot 7 \\
5 \cdot 6 \\
5.6 \\
7 \cdot 6 \\
5.0\end{array}$ & $\begin{array}{l}78 \\
80 \\
80 \\
88 \\
66 \\
68 \\
75 \\
66 \\
66 \\
66 \\
60\end{array}$ & $\begin{array}{r}74 \\
56 \\
46 \\
95 \\
120 \\
103 \\
76 \\
85 \\
85 \\
115 \\
83\end{array}$ & $\begin{array}{l}5 \cdot 7 \\
4 \cdot 6 \\
3 \cdot 7 \\
8 \cdot 6 \\
7 \cdot 5 \\
5 \cdot 4 \\
5 \cdot 9 \\
5 \cdot 4 \\
5 \cdot 4 \\
7 \cdot 2 \\
4 \cdot 7\end{array}$ & $\begin{array}{l}78 \\
76 \\
82 \\
90 \\
66 \\
72 \\
84 \\
62 \\
62 \\
72 \\
60\end{array}$ & $\begin{array}{r}73 \\
60 \\
45 \\
96 \\
114 \\
75 \\
70 \\
87 \\
87 \\
100 \\
78\end{array}$ \\
\hline $\begin{array}{l}\text { Mean } \\
\text { SD } \pm\end{array}$ & $\begin{array}{r}55.4 \\
9.6\end{array}$ & & $\begin{array}{l}6 \cdot 1 \\
1.5\end{array}$ & $\begin{array}{r}72 \cdot 1 \\
8.6\end{array}$ & $\begin{array}{l}85 \cdot 3 \\
22 \cdot 8\end{array}$ & $\begin{array}{l}5 \cdot 8 \\
1 \cdot 3\end{array}$ & $\begin{array}{r}73.1 \\
9.9\end{array}$ & $\begin{array}{l}80.5 \\
19.3\end{array}$ \\
\hline
\end{tabular}

TABLE III

RESULTS OF OBSERVATIONS IN 10 PATIENTS WITH PULMONARY OEDEMA AFTER MYOCARDIAL INFARCTION

\begin{tabular}{|c|c|c|c|c|c|c|c|c|}
\hline \multirow[b]{2}{*}{ Subject } & \multirow[b]{2}{*}{$\begin{array}{l}\text { Age } \\
\text { (yr.) }\end{array}$} & \multirow[b]{2}{*}{ Sex } & \multicolumn{3}{|c|}{ Supine observations } & \multicolumn{3}{|c|}{ Observations at $45^{\circ}$} \\
\hline & & & $\underset{(1 . / \mathrm{min} .)}{\text { Cardiac output }}$ & Pulse/min. & $\begin{array}{l}\text { Stroke volume } \\
\text { (ml.) }\end{array}$ & $\begin{array}{c}\text { Cardiac output } \\
\text { (1./min.) }\end{array}$ & Pulse/min. & \begin{tabular}{|c|}
$\begin{array}{c}\text { Stroke volume } \\
\text { (ml.) }\end{array}$
\end{tabular} \\
\hline $\begin{array}{l}\text { J.R. } \\
\text { A.F. } \\
\text { R.M.cI. } \\
\text { W.E. } \\
\text { R.S. } \\
\text { J.P. } \\
\text { A.M. } \\
\text { D.C. } \\
\text { A.E. } \\
\text { J.S. }\end{array}$ & $\begin{array}{l}65 \\
65 \\
50 \\
44 \\
56 \\
47 \\
56 \\
67 \\
48 \\
57\end{array}$ & $\begin{array}{l}M \\
M \\
M \\
M \\
M \\
M \\
M \\
M \\
M \\
M\end{array}$ & $\begin{array}{l}4 \cdot 4 \\
5 \cdot 0 \\
6 \cdot 4 \\
6 \cdot 2 \\
4 \cdot 8 \\
5 \cdot 5 \\
5 \cdot 1 \\
2 \cdot 2 \\
4 \cdot 0 \\
5 \cdot 9\end{array}$ & $\begin{array}{l}76 \\
72 \\
76 \\
72 \\
70 \\
88 \\
68 \\
78 \\
84 \\
92\end{array}$ & $\begin{array}{l}58 \\
69 \\
84 \\
86 \\
68 \\
63 \\
75 \\
28 \\
48 \\
64\end{array}$ & $\begin{array}{l}6 \cdot 5 \\
5 \cdot 7 \\
7 \cdot 5 \\
6 \cdot 6 \\
4 \cdot 5 \\
5 \cdot 7 \\
7 \cdot 6 \\
2 \cdot 7 \\
4.9 \\
8 \cdot 5\end{array}$ & $\begin{array}{l}76 \\
78 \\
76 \\
74 \\
70 \\
90 \\
66 \\
82 \\
88 \\
96\end{array}$ & $\begin{array}{r}86 \\
73 \\
99 \\
89 \\
64 \\
63 \\
115 \\
33 \\
56 \\
89\end{array}$ \\
\hline $\begin{array}{l}\text { Mean } \\
\text { SD } \pm\end{array}$ & $\begin{array}{r}55 \cdot 5 \\
8 \cdot 1\end{array}$ & & $\begin{array}{l}5 \cdot 0 \\
1 \cdot 2\end{array}$ & $\begin{array}{r}77 \cdot 6 \\
7.9\end{array}$ & $\begin{array}{l}64 \cdot 3 \\
17 \cdot 1\end{array}$ & $\begin{array}{l}6 \cdot 2 \\
1 \cdot 2\end{array}$ & $\begin{array}{r}79 \cdot 6 \\
9 \cdot 4\end{array}$ & $\begin{array}{l}77 \cdot 0 \\
23 \cdot 7\end{array}$ \\
\hline
\end{tabular}

Post-infarction Group (no pulmonary oedema, 11 subjects)-Group 2. The cardiac outputs of this group ranged from 3.7 to $8.41 . / \mathrm{min}$. (mean $6 \cdot 1 \pm 1.5$ ) when supine and from 3.7 to $8.61 . / \mathrm{min}$., with head raised (mean 5.8, $\mathrm{SD} \pm 1 \cdot 3$ ). Pulse rate (supine) ranged from 60 to $88 / \mathrm{min}$. (mean $72 \cdot 1, \mathrm{SD} \pm 8 \cdot 6$ ) and in the raised position it ranged from 60 to $90 / \mathrm{min}$. (mean $73 \cdot 1$, SD \pm 9.9 ). Stroke volume (supine) was from $46 \mathrm{ml}$. to $120 \mathrm{ml}$. (mean $85 \cdot 3, \mathrm{SD} \pm 22 \cdot 8$ ) and stroke volume with head raised was from 45 to $114 \mathrm{ml}$. (mean 80.5, SD $\pm 19 \cdot 3$ ) (Table II).

Post-infarction Patients (with pulmonary oedema, 10 
subjects)-Group 3. The cardiac output (supine) of this group ranged from $2 \cdot 2$ to $6 \cdot 41 . / \mathrm{min}$. (mean $5 \cdot 0$, SD $\pm 1 \cdot 2$ ), and with head raised ranged from 2.7 to 8.5 $1 . /$ min. (mean 6.0, $\mathrm{SD} \pm 1 \cdot 2$ ). Pulse rate in this group ranged from 68 to $92 / \mathrm{min}$. supine (mean $77 \cdot 6$, SD \pm 7.9 ) and from 70 to 96 in the raised position (mean $79 \cdot 6, \mathrm{SD} \pm 9 \cdot 4)$. Stroke volume ranged from 28 to 86 ml. supine (mean $64 \cdot 3, S D \pm 17 \cdot 1$ ) and from 33 to 123 $\mathrm{ml}$. in the $45^{\circ}$ raised position (mean 77.0, $\mathrm{SD} \pm 23.7$ ) (Table III).

The results for the three groups of subjects are summarized in Table IV.
Zöllner (1957) using a dye dilution method found a mean fall in cardiac output of 30 per cent (range 11-49) with the change from lying to standing. Similar findings have been recorded using the dye dilution technique by Chapman, Fisher, and Sproule (1960), Wang et al. (1960), and Reeves et al. (1961).

Levine $(1940,1944,1951)$ suggested that the work of the heart might be reduced if patients suffering from cardiac failure were propped up in bed or treated out of bed in an armchair. Coe (1954) examined some of Levine's patients and showed that

TABLE IV

MEAN RESULTS AND STANDARD DEVIATIONS OF CARDIAC OUTPUT, PULSE RATE, STROKE VOLUME FOR THREE GROUPS OF SUBJECTS

\begin{tabular}{|c|c|c|c|c|c|c|c|}
\hline & & \multicolumn{3}{|c|}{ Supine observations } & \multicolumn{3}{|c|}{ Observations at $45^{\circ}$} \\
\hline & & $\begin{array}{l}\text { Cardiac } \\
\text { output } \\
\text { (1./min.) }\end{array}$ & $\begin{array}{l}\text { Pulse } \\
\text { rate/min. }\end{array}$ & $\begin{array}{c}\text { Stroke } \\
\text { volume } \\
(\mathrm{ml} .)\end{array}$ & $\begin{array}{l}\text { Cardiac } \\
\text { output } \\
\text { (1./min.) }\end{array}$ & $\begin{array}{l}\text { Pulse } \\
\text { rate/min. }\end{array}$ & $\begin{array}{c}\text { Stroke } \\
\text { volume } \\
(\mathrm{ml} .)\end{array}$ \\
\hline $\begin{array}{l}\text { Normal controls } \\
\text { (10 subjects) }\end{array}$ & $\begin{array}{l}\text { Mean } \\
\text { SD } \pm\end{array}$ & $\begin{array}{l}6 \cdot 8 \\
2 \cdot 4\end{array}$ & $\begin{array}{ll}71 \cdot 4 \\
13 \cdot 3\end{array}$ & $\begin{array}{l}96 \cdot 3 \\
31 \cdot 7\end{array}$ & $\begin{array}{l}7 \cdot 2 \\
2 \cdot 4\end{array}$ & $\begin{array}{l}71 \cdot 6 \\
12 \cdot 7\end{array}$ & $\begin{array}{r}100 \cdot 7 \\
27 \cdot 3\end{array}$ \\
\hline $\begin{array}{l}\text { Infarct patients (no pulm. oedema) } \\
\text { (11 subjects) }\end{array}$ & $\begin{array}{l}\text { Mean } \\
\mathrm{SD} \pm\end{array}$ & $\begin{array}{l}6 \cdot 1 \\
1 \cdot 5\end{array}$ & $\begin{array}{r}72 \cdot 1 \\
8 \cdot 6\end{array}$ & $\begin{array}{l}85 \cdot 3 \\
22 \cdot 8\end{array}$ & $\begin{array}{l}5 \cdot 8 \\
1 \cdot 3\end{array}$ & $\begin{array}{r}73 \cdot 1 \\
9 \cdot 9\end{array}$ & $\begin{array}{l}80 \cdot 5 \\
19 \cdot 3\end{array}$ \\
\hline $\begin{array}{l}\text { Infarct patients (with pulm. oedema) } \\
\text { (10 subjects) }\end{array}$ & $\begin{array}{l}\text { Mean } \\
\text { SD } \pm\end{array}$ & $\begin{array}{l}5 \cdot 0 \\
1 \cdot 2\end{array}$ & $\begin{array}{r}77 \cdot 6 \\
7.9\end{array}$ & $\begin{array}{l}64 \cdot 3 \\
17 \cdot 1\end{array}$ & $\begin{array}{l}6 \cdot 0 \\
1 \cdot 2\end{array}$ & $\begin{array}{r}79 \cdot 6 \\
9 \cdot 4\end{array}$ & $\begin{array}{l}77 \cdot 0 \\
23 \cdot 7\end{array}$ \\
\hline
\end{tabular}

Note: Significant differences are found between mean cardiac output of infarct patients with pulmonary oedema in supine and raised position $(t 3.7, p<0.01)$, and in mean stroke volume in this group $(t 2.85, p<0.02)$ (paired $t$ test, Hill, 1966).

\section{Discussion}

Cardiac output has been shown to be less in the erect position than in the supine (McMichael, 1938; McMichael and Sharpey-Schafer, 1944; Weissler, Leonard, and Warren, 1957; Wang, Marshall, and Shepherd, 1960). Starr and Rawson (1941) using the technique of ballistocardiography showed that the response to tilting in normal subjects is variable, and showed that similar variability could be found in many of the previously published reports. They estimated cardiac outputs between one and two and a half minutes after putting their subjects into the vertical position. Most of the other reports do not record the time interval that elapsed between the change of position and the cardiac output estimation.

McMichael and Sharpey-Schafer (1944), using Fick principle methods, showed that with the change from the supine to the erect position cardiac output fell an average of $1.51 . / \mathrm{min}$.

Stead et al. (1945) studied the effect of passive tilting from the recumbent to the $70^{\circ}$ head-up position. This produced a decrease of cardiac output in each of 6 subjects, the mean fall being 0.8 $1 . / \mathrm{min} . / \mathrm{m}^{2}{ }^{2}$ body surface. Nowy, Kikodse, and cardiac work was less while patients were seated by the bedside (mean decrease of $23 \%$ ).

Donald et al. (1953) studied the nursing position of 36 patients and found that changes in position resulted in a significant change in cardiac output but concluded that these changes were unlikely to be of much benefit to any patient.

It is well documented therefore that a change in cardiac output can be produced by changes in position, and that the load on the heart after myocardial infarction can be reduced by sitting patients in bed.

The results of the present investigation indicate that there were small but insignificant differences in sitting and supine cardiac outputs in the group of normal controls and in the group of patients who had sustained a myocardial infarction and in whom there was no evidence of cardiac decompensation. There was almost no change in pulse rate associated with the postural change and little change in stroke volume. It appears that the postural change is less than when the whole individual is tilted to the $45^{\circ}$ head-up position which has been reported previously to produce a fall in cardiac output.

In the group of normal controls it was found that cardiac output was greater in the propped-up position in 6 subjects, less in 2, and there was no change 
in 2. The mean change was $0.41 . / \mathrm{m}$., but this was not significant.

The group of infarct patients who did not show evidence of pulmonary oedema showed a small difference in cardiac output (mean change $0.31 . / \mathrm{m}$.). This was not significant at the 0.05 level of probability. Of these patients, 7 had a smaller cardiac output in the seated position than in the supine, 2 had a larger output, and 2 showed no change.

Ten patients were examined after myocardial infarction at a time when they showed radiological evidence of pulmonary oedema. The cardiac output in 9 of the patients was greater in the seated position than in the supine. In the tenth patient the cardiac output was smaller in the seated position. The mean difference of $1.01 . / \mathrm{min}$. is statistically significant $(p<0.01)$.

The rise in cardiac output is due to a rise in a stroke volume (mean difference of $12.7 \mathrm{ml}$.) and can be explained according to Starling's theory. The load on the failing heart has been decreased by putting the patient into a sitting posture and thus reducing venous return. Since stroke volume is a measurement of the ability of ventricles to contract (Nager, Thomas, and Shillingford, 1967), it appears that ventricular contractility has been improved by placing the patient in the $45^{\circ}$ head-up position.

The mean cardiac outputs and mean stroke volumes of the normal controls were higher than those of the infarct patients. This might be accounted for by the lower ages of the normal controls (Wade and Bishop, 1962). The mean cardiac outputs and mean stroke volumes of the infarct patients with pulmonary oedema were lower than those of the patients who did not have pulmonary oedema.

\section{SUMmary AND CONCLUSIONS}

Cardiac outputs have been estimated by a dye dilution technique in three groups of patients in the supine and in the $45^{\circ}$ head-raised position with legs extended.

The three groups were (a) 10 subjects without evidence of cardiac or respiratory disease; (b) 11 patients who had sustained a myocardial infarction and in whom there was no evidence of pulmonary oedema; and (c) 10 patients who had sustained a myocardial infarction and in whom there was evidence of pulmonary oedema.

The results indicate that the cardiac output of normal subjects and of patients who have sustained a myocardial infarction but who do not show evidence of pulmonary oedema is only slightly influenced by the change in posture involved in moving from the supine to the sitting position. The changes induced are not statistically significant and are unlikely to be important in the management of the individual patient. Significant changes were seen in the group of patients who had sustained a myocardial infarction and who had radiological evidence of pulmonary oedema. The mean cardiac output of this group was significantly greater when sitting in bed than when lying supine. Of the 10 patients in this group, 9 had a greater cardiac output when sitting than when supine. The increase in cardiac output is considered to arise in the way that Starling (1918) has suggested for the failing denervated heart by a reduction in venous return associated with the change of posture. The increase in cardiac output might be of clinical significance in promoting clearing of pulmonary oedema and improving tissue perfusion.

I would like to express my gratitude to the Pharmaceutical Division of I.C.I. for supplies of Coomassie Blue, to Drs. Gavin Shaw and John Robinson for helpful advice in the preparation of the manuscript, and to the nursing staff and the cardiological technicians of the Southern General Hospital for their co-operation in the cardiac output estimations.

\section{REFERENCES}

Bruce, T. A., and Shillingford, J. P. (1962). The normal resting cardiac output: serial determinations by a dye dilution method. Brit. Heart f., 24, 69.

Chapman, C. B., Fisher, J. N., and Sproule, B. J. (1960). Behavior of stroke volume at rest and during exercise in human beings. $\mathcal{F}$. clin. Invest., 39, 1208.

Coe, W. S. (1954). Cardiac work and the chair treatment of acute coronary thrombosis. Ann. intern. Med., 40, 42.

Dacie, J. V., and Lewis, S. M. (1963). Practical Haematology, 3rd ed. Churchill, London.

Donald, K. W., Bishop, J. M., Cumming, G., and Wade, O. L. (1953). The effect of nursing positions on the cardiac output in man, with a note on the repeatability of measurements of cardiac output by the direct Fick method and with data on subjects with normal cardiovascular system. Clin. Sci., 12, 199.

Gabe, I., and Shillingford, J. (1961). The photo-electric earpiece technique for recording dye dilution curves. Brit. Heart $\mathcal{F}$., 23, 271.

-, Tuckman, J., and Shillingford, J. P. (1962). Determination of relative changes in cardiac output from noncalibrated earpiece dye-dilution curve. Circulat. Res., 11, 405.

Hill, A. Bradford (1966). Principles of Medical Statistics, 8th ed. The Lancet, London.

Levine, S. A. (1940). The management of patients with heart failure. F. Amer. med. Ass., 115, 1715.

- (1944). Some harmful effects of recumbency in the treatment of heart disease. F. Amer. med. Ass., 126, 80.

- (1951). The myth of strict bed rest in the treatment of heart disease. Amer. Heart F., 42, 406.

McMichael, J. (1938). Postural changes in cardiac output and respiration in man. I. The acetylene method of measuring cardiac output. Quart. F. exp. Physiol., 27, 55. 
—, and Sharpey-Schafer, E. P. (1944). Cardiac output in man by a direct Fick method. Effects of posture, venous pressure change, atropine, and adrenaline. Brit. Heart f., 6, 33.

Nager, F., Thomas, M., and Shillingford, J. (1967). Changes in cardiac output and stroke volume during first four months after cardiac infarction. Brit. Heart f., 29, 859.

Nowy, H., Kikodse, K., and Zöllner, N. (1957). Vergleichende Messungen des zentralen Blutvolumens und Herzminutenvolumens im Liegen und im Stehen. $Z$. Kreisl.-Forsch., 46, 393.

Reeves, J. T., Grover, R. F., Blount, S. G., and Filley, G. F. (1961). Cardiac output response to standing and treadmill walking. F. appl. Physiol., 16, 283.

Starling, E. H. (1918). The Linacre Lecture on the Law of the Heart, given at Cambridge, 1915. Longmans, Green, London.

Starr, I., and Rawson, A. J. (1941). The vertical ballistocardiograph; experiments on the changes in the circu- lation on arising; with a further study of ballistic theory. Amer. F. Physiol., 134, 403.

Stead, E. A., Warren, J. V., Merrill, A. J., and Brannon, E. S. (1945). The cardiac output in male subjects as measured by the technique of right atrial catheterization. Normal values with observations on the effect of anxiety and tilting. F. clin. Invest., 24, 326.

Thomas, M., Malmcrona, R., and Shillingford, J. (1965). Hemodynamic changes in patients with acute myocardial infarction. Circulation, 31, 811.

Wade, O. L., and Bishop, J. M. (1962). Cardiac Output and Regional Blood Flow. Blackwell, Oxford.

Wang, Y., Marshall, R. J., and Shepherd, J. T. (1960). The effect of changes in posture and of graded exercise on stroke volume in man. $\mathcal{F}$. clin. Invest., 39, 1051.

Weissler, A. M., Leonard, J. J., and Warren, J. V. (1957). Effects of posture and atropine on the cardiac output. f. clin. Invest., 36, 1656. 